\title{
The Determinants of Commitment Escalation (Experimental Study: Covid-19 Pandemic as A Contextual)
}

\author{
Dyna Rachmawati ${ }^{1}$ Patricia Felin Budianto $^{2}$ \\ Widya Mandala Catholic, University Surabaya, INDONESIA ${ }^{1,2}$
}

\begin{tabular}{l}
\hline \hline ARTICLE INFO \\
\hline \hline Article history: \\
Received: Dec 06,2021 \\
Revised: Jan 23, 2022 \\
Accepted: Feb 15, 2022 \\
\hline Keywords: \\
covid-19 pandemic; adverse \\
selection; framing; reward and \\
punishment; commitment escalation \\
\hline Correspondence: \\
Dyna Rachmawati \\
dyna@ $u k w m s . a c . i d$
\end{tabular}

How to cite (APA Style):

Budianto, P.F., Rachmawati, Dyna. (2022). The Determinants of Commitment Escalation (Experimental Study: Covid19 Pandemic as A Contextual). Jurnal Akuntansi, 12(1), 13-22 https://doi.org/10.33369/j.akuntansi.12.1.13-22

\section{INTRODUCTION}

In general, an organization will be confronted with situations that demand it to make decisions about solutions to minor or major issues. Managers as a person who have leadership functions with intuition and analytical abilities are needed when making decisions in situations full of uncertainty (David and David, 2016:5). The COVID-19 pandemic, for example, has created economic conditions that are unfavorable to specific industrial sectors, putting business continuity at risk if managers make poor judgments that do not reflect the current situation. Wrong decision-making (process) can be caused by the manager's actions where he justifies past decisions he has made (Daft, 2014: 302). A person will tend to defend his decision because it is said that no one likes to make mistakes, so (they) will increase commitment to the wrong decision with the intent and purpose of correcting it. This increased commitment is commonly known as commitment escalation, namely the tendency of a person to continue his decision even though it is not profitable or economically stated if the decision shows potential failure (Radianto, 2018: 22). The tendency for commitment escalation may be increasingly found during the Covid-19 pandemic considering that decision-making can become more vulnerable to failure due to high risk, time pressure, problem complexity, and uncertain circumstances. 
Escalation of commitment can be caused by several factors. The first factor is the adverse selection which can be related to agency theory. This theory consists of 2 parties, namely the principal as the owner, and the agent as the manager where it is stated that in the decision-making process, there can be differences in interests between the two parties so that the existing project is continued even though it does not maximize profits for the company. Adverse selection describes the existence of information asymmetry between one or more parties who have more information than the other party (Scott, 2015: 23).

Previous research by Sari and Wirakusuma (2017), Soma and Restuti (2017), Yusra and Atika (2017) has proven that adverse selection has a positive effect on commitment escalation. This means that if a manager has more (less) private information or neglects his duty to communicate the information he knows, the tendency to escalate commitment is higher (lower). However, this result is contrary to Helmayunita (2015) which states that adverse selection does not affect commitment escalation.

The second factor that affects the escalation of commitment is framing or information framing. The framing effect means that a person's decision is influenced by the way information is framed (Kessler, 2013: 82). This factor can be related to prospect theory which explains that a person will tend to take risks when faced with situations that show potential losses than when faced with potential gains. Therefore, there is a tendency for managers to be more careful to avoid risk (risk-averse) by terminating the project if the information is shown in a positive framing condition. Conversely, when information is shown in conditions that indicate a loss (negative framing), managers will take risky decisions by continuing to run the project.

The results of research by Sari and Wirakusuma (2017), Yusra and Atika (2017) have proven that negative framing has a positive effect on commitment escalation. This indicates that if the information is presented with negative framing (positive framing), the tendency to escalate commitment is higher (lower). However, this result is contrary to Sulistiyo (2019) which states that framing does not affect commitment escalation.

Motivated managers will be more inspired to make better decisions and think differently. Incentive mechanisms and compensation systems are often used as motivation to encourage someone to act in such a way that organizational goals are achieved (Anthony, et al., 2007: 249). Incentives can be in the form of positive incentives or rewards and negative incentives or punishments. This incentive scheme can also be linked to agency theory where the agent and principal have different preferences or goals, but the incentive contract is expected to harmonize these differences in preferences. The problem that may occur is when managers who are motivated by incentives can do everything they can to get the award and then encourage them to escalate commitment. Research conducted by Putri (2018) proves that there is a positive effect of reward and punishment on commitment escalation. The results of this study mean that if employees get (not get) incentives in the form of rewards and punishments, the probability of commitment escalation becomes higher (lower).

This study examines the effect of non-interaction and interaction effects on adverse selection variables, information framing, and the application of a reward and punishment system on commitment escalation. The non-interaction effect was tested with a two-way ANOVA, and a one-way ANOVA test for the interaction effect. Previous research on the effect of adverse selection and information framing on commitment escalation is still inconsistent. Meanwhile, previous research examining the impact of reward and punishment on commitment escalation is still limited. This is the main objective of this research. And previous research has not used the COVID-19 pandemic as a contextual tool. to test the effect of adverse selection, information framing, and the application of a reward and punishment system on commitment escalation.

This research proves that first, adverse selection has a weak positive effect on commitment escalation. This means that information asymmetry during the pandemic is low so 
the tendency of management to escalate commitment is also low. This happens when there is no application of a reward and punishment system and negative information framing, then management with a high level of information asymmetry tends to escalate commitment compared to management with a low level of information asymmetry.

Second, framing harms commitment escalation. Framing negative information will tend to increase commitment escalation compared to framing positive information. Testing the interaction effect in the presence and absence of adverse selection, as well as the presence and absence of the application of a reward and punishment system, negative framing tends to increase commitment escalation compared to positive framing. This means that framing has an important role in the escalation of commitments during the COVID-19 pandemic. The results of previous studies also prove that framing negative information leads to a higher commitment escalation than framing positive information. In conclusion, framing is a determinant that can affect the escalation of commitment.

The third is that the application of the reward and punishment system is not a determinant of commitment escalation. The results of the non-interaction and interaction test show that the application of the reward and punishment system is not significant to the escalation of commitment. This means that the application of the reward and punishment system is irrelevant during the pandemic. The company experienced the same condition, namely the difficulty of selling and bringing in raw materials due to the government's imposition of restrictions on community activities.

This research contributes both academically and practically. The academic contribution is the use of the COVID-19 pandemic as contextual in experimental studies to examine the determinants that affect commitment escalation. The practical contribution is first, information asymmetry during the covid-19 pandemic between shareholders and lower management. Therefore, the tendency of management to escalate commitment is also low. Second, framing is an important determinant that affects the escalation of commitment. Therefore, if management seeks to reduce the escalation of commitment, it must collect positive information before making long-term decisions. Third, shareholders need to reconsider the reward and punishment system because it does not affect the escalation of commitments during the pandemic. The COVID-19 pandemic has resulted in many obstacles for organizations, especially in the tourism sector, so the implementation of the reward and punishment system will be full of policies.

Agency theory underlies the development of this research hypothesis, namely that there are differences in the interests of the principal and the agent that cause adverse selection problems or information asymmetry. This occurs when the information submitted by the agent to the principal is not in line with the original condition. When the agent has private information that is not known to the principal, the agent or manager can escalate the commitment. The agent or manager puts his interests first by continuing a losing project and hoping that it will eventually generate financial gain and also preserve his reputation. For example, in a Covid-19 pandemic situation, a manager may intentionally not convey information related to a project situation that suffers losses due to the implementation of regulations related to Covid-19 to allow managers to escalate commitments (Sari and Wirakusuma, 2017; Soma and Restuti, 2017; Yusra and Atika, 2017). Therefore, the hypothesis made is as follows:

$\mathrm{H}_{1}$ : In conditions of adverse selection, the tendency for commitment escalation is higher than in conditions where there is no adverse selection

$\mathrm{H}_{1 \mathrm{a}}$ : In conditions where there is reward and punishment and in framing positive information, the tendency for commitment escalation is higher when in adverse selection conditions.

$\mathrm{H}_{1 \mathrm{~b}}$ : In conditions without reward and punishment and in framing positive information, the tendency for commitment escalation is higher when in adverse selection conditions. 
$\mathrm{H}_{1 \mathrm{c}}$ : In conditions where there are rewards and punishments and in framing negative information, the tendency for commitment escalation is higher when in adverse selection conditions.

$\mathrm{H}_{1 \mathrm{~d}}$ : In conditions without reward and punishment and in framing negative information, the tendency for commitment escalation is higher when in adverse selection conditions.

Prospect theory explains that the difference in decisions depends on the processing of information that will provide an advantage or disadvantage. Understanding information is important before making a decision. This is also related to the way the information is presented. Information in positive framing makes managers tend to be careful and avoid risk so that the escalation of commitment is low. On the other hand, negative information framing causes managers to tend to take risky decisions, thereby increasing commitment escalation (Sari and Wirakusuma, 2017; Yusra and Atika, 2017; Sulistiyo, 2019). Therefore, the hypothesis made is as follows:

$\mathrm{H}_{2}$ : In conditions of framing negative information, the tendency for commitment escalation is higher than framing positive information.

$\mathrm{H}_{2 \mathrm{a}}$ : In adverse selection conditions and there are rewards and punishments, the tendency to escalate commitment is higher in framing negative information than in framing positive information.

$\mathrm{H}_{2 \mathrm{~b}}$ : In adverse selection conditions and there is no reward and punishment, the tendency for commitment escalation is higher in framing negative information than framing positive information.

$\mathrm{H}_{2 \mathrm{c}}$ : In conditions where there is no adverse selection and there is reward and punishment, the tendency for commitment escalation is higher in framing negative information than framing positive information.

$\mathrm{H}_{2 \mathrm{~d}}$ : In the condition that there is no adverse selection and no reward and punishment, the tendency for commitment escalation is higher in framing negative information than in framing positive information.

Agency theory states that agency problems can be reduced if there is an incentive mechanism. The agent works for the principal and in return will receive a reward for his work. The problem is the relationship between the agent and the principal is the difference in the interests they have. Agents are employed by principals for the benefit of a company, but agents tend to prioritize their welfare. In addition, there are also problems related to agents working to take advantage of the incentive system. Agents who are motivated by incentives can do everything they can to get the promised rewards, especially when facing an urgent situation such as the Covid-19 pandemic. Thus, this can lead to an escalation of commitments where agents continue unprofitable projects in the hope that these projects can become profitable in the future (Putri, 2018). Therefore, the hypothesis made is as follows:

$\mathrm{H}_{3}$ : In conditions where there is reward and punishment, the tendency for commitment escalation is higher than there is no reward and punishment

$\mathrm{H}_{3 \mathrm{a}}$ : In conditions where there is an adverse selection and positive information framing, the tendency for commitment escalation is higher when there is reward and punishment.

$\mathrm{H}_{3 \mathrm{~b}}$ : In conditions where there is no adverse selection and positive information framing, the tendency for commitment escalation is higher when there are rewards and punishments.

$\mathrm{H}_{3 \mathrm{c}}$ : In conditions where there is adverse selection and in the framing of negative information, the tendency to escalate commitment is higher when there is reward and punishment.

$\mathrm{H}_{3 \mathrm{~d}}$ : In conditions where there is no adverse selection and in framing negative information, the tendency for commitment escalation is higher when there is reward and punishment. 
The conceptual framework of research based on hypotheses can be described as follows:

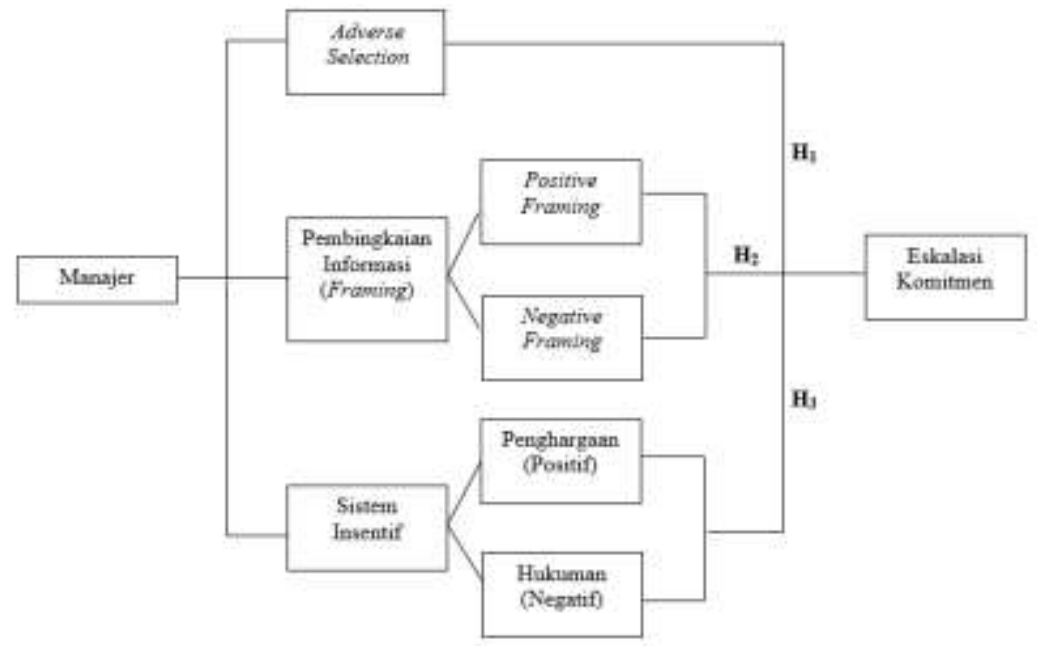

Figure 1 Conceptual Framework

\section{RESEARCH METHODS}

This study uses a quantitative research methodology to test the hypothesis, which is to determine the impact and link between the independent variables adverse selection, information framing, and the application of a reward and punishment system on the dependent variable escalation of commitment. Experiments are organized into 8 cases or scenarios with each case requiring a minimum of 15 respondents. Respondents are positioned as senior managers who must make decisions regarding the sustainability of project investment amid the Covid-19 pandemic under certain conditions. For example, for case A, the respondent is placed in a position of adverse selection and the application of a reward and punishment system, and is in a condition of positive information framing. The rest can be seen in Table 1 below:

Table 1. 2x2x2 Between Subject and Within Subject

\begin{tabular}{cccc}
\hline & & \multicolumn{2}{c}{ Information Framing } \\
\cline { 2 - 4 } & & Positive & Negative \\
\hline Adverse & Reward and Punishment & $\mathrm{A}$ & $\mathrm{E}$ \\
\cline { 2 - 4 } & Without Reward and Punishment & $\mathrm{B}$ & $\mathrm{F}$ \\
\hline \multirow{2}{*}{$\begin{array}{c}\text { Without Adverse } \\
\text { Selection }\end{array}$} & Reward and Punishment & $\mathrm{C}$ & $\mathrm{G}$ \\
\cline { 2 - 4 } & Without Reward and Punishment & $\mathrm{D}$ & $\mathrm{H}$ \\
\hline
\end{tabular}

The tendency for commitment escalation will be measured using a Likert scale measuring 1-10. A scale of 1 indicates a decision to terminate the project, while a number closer to 10 indicates a decision to continue with the project. The purpose of this research is to find out whether the actions taken by the respondent will be the same or not if the respondent is faced with a situation similar to the perpetrator.

The condition of adverse selection in the questionnaire is indicated by the leader who knows the condition of the investment project. Meanwhile, the condition of the absence of adverse selection is indicated by the leadership not knowing information related to the condition of the investment project.

Positive information framing in the scenario is described in a situation where if the project does not continue then the manager can save unused funds for the project. Meanwhile, if the project continues there is a small chance of recovering the entire investment money, but there is a high possibility that no funds will be recovered and left. On the other hand, negative information framing is displayed in the condition that the company will suffer a loss of the 
funds that have been used for the project if the project is terminated. Meanwhile, there is a small chance of no loss at all, but there is a high probability of full loss if the project continues.

Rewards in this case are in the form of bonuses that can be obtained if the project is successful. Meanwhile, punishment is in the form of an obligation to bear a certain percentage of the loss if the project harms the company which can threaten the respondent's position or position as a senior financial manager in the scenario case.

Experimental research was conducted on undergraduate students of the Accounting study program at Widya Mandala Catholic University, Surabaya. The experimental scenario was distributed using a google form from October 21 to November 9, 2021, through the Line and Whatsapp applications. Furthermore, sampling was carried out using the purposive sampling technique, namely the selection of samples based on criteria that must be met, namely students who had completed financial management or management accounting courses. In addition, the data can be processed further if the respondent can answer the 3 manipulation check questions correctly to ensure that the respondent understands the story and the case questions. Furthermore, the hypothesis that has been made will then be tested with ANOVA or Analysis of Variance. Non-interaction effects will be tested using a two-way ANOVA. Then additional tests will be carried out for interaction effects using one-way ANOVA.

\section{RESULTS AND DISCUSSION}

The research data that was collected from the respondents amounted to 169 . The results of the manipulation check showed 120 respondents who passed and data processing could be done.

\section{Adverse selection on commitment escalation}

Table 2 below shows the results of testing $\mathrm{H} 1$ with two-way ANOVA and $\mathrm{H}_{1 \mathrm{a}}$ to $\mathrm{H}_{1 \mathrm{~d}}$ with one-way ANOVA.

Table 2. Hypothesis 1 Testing

\begin{tabular}{lccc}
\hline & $\mathrm{F}$ & Sig. & Conclusion \\
\hline Adverse selection & 3.149 & $0.079 *$ & $\mathrm{H}_{1}$ accepted \\
\hline 1a (A-C) & 0.007 & 0.936 & $\mathrm{H}_{1 \mathrm{a}}$ rejected \\
\hline $1 \mathrm{~b}(\mathrm{~B}-\mathrm{D})$ & 0.202 & 0.656 & $\mathrm{H}_{1 \mathrm{~b}}$ rejected \\
\hline $1 \mathrm{c}(\mathrm{E}-\mathrm{G})$ & 1.719 & 0.200 & $\mathrm{H}_{1 \mathrm{c}}$ rejected \\
\hline 1d (F-H) & 5.259 & $0.030 * *$ & $\mathrm{H}_{1 \mathrm{~d}}$ accepted \\
\hline$* *$ significant at p-value $0.05 ; *$ significant at p-value 0.10 &
\end{tabular}

Adverse Selection individually can be said to be marginally significant because the significance number is 0.079 or below $0.1(10 \%)$ so the researcher's confidence is $90 \%$. The mean value of commitment escalation in the presence or absence of adverse selection is 5.95 and 5.32, respectively. The difference in the mean value of commitment escalation is very small, namely 0.63 so that with two-way ANOVA the result is marginally significant. The results of the $\mathrm{H}_{1}$ test are accepted. In conditions of adverse selection, it will encourage a tendency to escalate commitments. However, the significance is at the $90 \%$ confidence level. This means that adverse selection is a weak determinant of commitment escalation. Adverse selection or information asymmetry between principals (shareholders) and agents (managers) is low or almost no difference, so the impact on commitment escalation is weak during the covid-19 pandemic. This pandemic makes principals and agents have almost the same information. The principal can predict the effectiveness of the project chosen by the agent, in this experimental study it is a tourism project. The imposition of restrictions on community activities by the government is a factor constraining tourism projects. This is already known by the principal. The results of this study confirm the results of previous studies which have proven 
that adverse selection encourages commitment escalation (Sari and Wirakusuma, 2017; Soma and Restuti, 2017; Yusra and Atika, 2017).

Table 2 above also shows the results of testing $\mathrm{H}_{1 \mathrm{a}}$ to $\mathrm{H}_{1 \mathrm{c}} . \mathrm{H}_{1 \mathrm{a}}$ to $\mathrm{H}_{1 \mathrm{c}}$ showed a significance level of $\mathrm{p}>0.05$ so it was rejected and it was stated that there was no difference in commitment escalation. Meanwhile, $\mathrm{H}_{1 \mathrm{~d}}$ shows a significance of $\mathrm{p}<0.05$, which is 0.03 . This means that $\mathrm{H}_{1 \mathrm{~d}}$ is accepted. The test results for $\mathrm{H}_{1 \mathrm{a}}, \mathrm{H}_{1 \mathrm{~b}}$, and $\mathrm{H}_{1 \mathrm{c}}$ support the results of the $\mathrm{H}_{1}$ test. The test results show that the presence or absence of adverse selection is not a determinant of commitment escalation.

$\mathrm{H}_{1 \mathrm{~d}}$ is the only accepted hypothesis. This means that in conditions where there is no application of a reward and punishment system and negative information framing, adverse selection leads to a higher commitment escalation than no adverse selection. This experimental study tested the differences between groups $\mathrm{F}$ and $\mathrm{H}$. These two groups were under conditions of negative information framing and without the application of reward and punishment with differences in the presence or absence of adverse selection. This statistical difference between the two groups was contributed by the negative framing of information. Framing is a strong determinant of commitment escalation.

\section{Framing on commitment escalation}

Table 3 below shows the results of the $\mathrm{H}_{2}$ test with two-way ANOVA and $\mathrm{H}_{2 \mathrm{a}}$ to $\mathrm{H}_{2 \mathrm{~d}}$ with one-way ANOVA.

Table 3. Hypotheses 2 Testing

\begin{tabular}{cccc}
\hline & $\mathrm{F}$ & Sig. & Conclusions \\
\hline Framing & 98.009 & $0.000 * * *$ & $\mathrm{H}_{2}$ accepted \\
\hline 2a (A-E) & 32.474 & $0.000 * * *$ & $\mathrm{H}_{2 \mathrm{a}}$ accepted \\
\hline 2b (B-F) & 58.930 & $0.000 * * *$ & $\mathrm{H}_{2 \mathrm{~b}}$ accepted \\
\hline 2c $(\mathrm{C}-\mathrm{G})$ & 15.084 & $0.001 * * *$ & $\mathrm{H}_{2 \mathrm{c}}$ accepted \\
\hline 2d (D-H) & 14.035 & $0.001 * * *$ & $\mathrm{H}_{2 \mathrm{~d}}$ accepted \\
\hline$* * *$ significant at p-value 0.01 & &
\end{tabular}

The two-way ANOVA test shows that framing has a positive effect on commitment escalation. $\mathrm{H}_{2}$ this study is accepted, managers with negative information framing tend to escalate commitment compared to positive framing. Nilai mean eskalasi komitmen pada pembingkaian positif sebesar 3.867, sedangkan pada pembingkaian negatif sebesar 7.4. The mean value of commitment escalation on negative framing is higher than positive framing. Therefore, the results of the framing test (table 3) are statistically significant. $\mathrm{H}_{2}$ is proven empirically. Managers with negative information frames have a higher tendency to escalate commitment than positive information frames.

Table above also shows that the results of the one-way ANOVA test confirm the two-way ANOVA. $\mathrm{H}_{2 \mathrm{a}}$ to $\mathrm{H}_{2 \mathrm{~d}}$ is proven empirically. The results of this hypothesis test state that negatively framed information influences a person to escalate commitment compared to framing positive information during a pandemic. In this experimental study, the Covid-19 pandemic made a person choose to just play it safe, thus saving the remaining funds. However, this study uses the word loss with a small opportunity to recover the investment as a negative frame. Therefore, framing negative information during the COVID-19 pandemic encourages someone to dare to take risks and continue the project with the hope that he can get better profits or results in the future for the losses is experiencing. These results confirm the results of previous studies (Sari and Wirakusuma, 2017; Yusra and Atika, 2017; Sulistiyo, 2019) which did not use the COVID-19 pandemic as a contextual factor. This means that framing is the strongest determinant of commitment escalation compared to adverse selection and the application of a reward and punishment system. 
The Determinants of Commitment Escalation (Experimental Study: Covid-19 Pandemic as A Contextual)

Patricia Felin Budianto and Dyna Rachmawati

\section{Reward and punishment on commitment escalation}

Table below shows the results of the $\mathrm{H}_{3}$ test with two-way ANOVA and $\mathrm{H}_{3 \mathrm{a}}-\mathrm{H}_{3 \mathrm{~d}}$ with one-way ANOVA.

Table 4. Hypothesis 3

\begin{tabular}{lccc}
\hline & $\mathrm{F}$ & Sig. & Conclusions \\
\hline Reward and punishment & 0.035 & 0.852 & $\mathrm{H}_{3}$ rejected \\
\hline 3a $(\mathrm{A}-\mathrm{B})$ & 0.041 & 0.842 & $\mathrm{H}_{3 \mathrm{a}}$ rejected \\
\hline 3b $(\mathrm{C}-\mathrm{D})$ & 0.090 & 0.767 & $\mathrm{H}_{3 \mathrm{~b}}$ rejected \\
\hline 3c $(\mathrm{E}-\mathrm{F})$ & 0.119 & 0.733 & $\mathrm{H}_{3 \mathrm{c}}$ rejected \\
\hline 3d $(\mathrm{G}-\mathrm{H})$ & 0.235 & 0.632 & $\mathrm{H}_{3 \mathrm{~d}}$ rejected \\
\hline
\end{tabular}

Table 4 above shows the results of the two-way ANOVA test. The application of the reward and punishment system is not significant to the escalation of commitment. $\mathrm{H}_{3}$ is not supported empirically. The mean value of commitment escalation in conditions where there is and there is no application of the reward and punishment system is 5.667 and 5.6, respectively. Therefore, reward and punishment are not significant to the escalation of commitment. This means that there is no difference in the escalation of commitment to the condition that there is or there is no reward and punishment during the covid-19 pandemic.

Table 4 above also shows that the one-way ANOVA test results confirm the two-way ANOVA test results. $\mathrm{H}_{3 \mathrm{a}}$ through $\mathrm{H}_{3 \mathrm{~d}}$ are not empirically supported. This experimental study uses a bonus in the form of money as a reward, while punishment is in the form of a certain percentage that must be borne by the manager if the project fails. The COVID-19 pandemic is a context that is considered to greatly affect the effectiveness of tourism projects. This causes respondents who act as managers to assume that there is a 50\% chance of failure and a $50 \%$ chance of success, whether or not there is an application of a reward and punishment system. The results of this study are different from the results of Putri's research (2018) which has proven that the application of a reward and punishment system will encourage commitment escalation. The difference between the results of this study and previous studies could be due to the use of the COVID-19 pandemic as contextual in this study. The results of this test concluded that the application of the reward and punishment system is not a determinant during the covid-19 pandemic.

\section{CONCLUSIONS AND SUGGESTION}

This study concludes that adverse selection is a weak determinant of commitment escalation during the COVID-19 pandemic. The COVID-19 pandemic has resulted in a low information asymmetry between principals and agents, thereby reducing the tendency for agents to escalate commitments. Second, framing is the strongest determinant of commitment escalation compared to adverse selection and the application of a reward and punishment system. Negative framing conditions tend to increase commitment escalation compared to positive framing during the COVID-19 pandemic. Previous research that did not use the COVID-19 pandemic as contextual also proved that negative framing led to an escalation of commitment. Framing is a strong determinant of commitment escalation both during the pandemic and non-pandemic. Third, the application of the reward and punishment system is not a determinant of commitment escalation during the COVID-19 pandemic. Tourism projects during the COVID-19 pandemic will experience many obstacles due to the imposition of restrictions on community activities. This indicates that during the pandemic the agent takes a $50 \%$ chance of succeeding and 50\% failing, there is or there is no application of a reward and punishment system.

This research has both academic as well as practical contributions. The academic contribution is the use of the COVID-19 pandemic as a contextual factor to test the determinants of commitment escalation. Future research can continue by using real managers in the tourism 
or transportation industry or other industries that have been negatively affected by the COVID19 pandemic. The contribution of practice is first, managers need to use information in a positive frame before making decisions that have long-term consequences. Positive frame information can reduce the tendency for commitment escalation. Second, information asymmetry during the pandemic is low, so the tendency for commitment escalation is also low. Therefore, shareholders do not have to worry about management's efforts to hide information about the project. Information about tourism projects during the covid-19 pandemic that is owned by managers will not be much different from shareholders. Third, the implementation of the reward and punishment system can be reconsidered by shareholders, especially in the provision of rewards in the form of cash bonuses and punishment in the form of reducing financial compensation. Implementation of this system will not reduce or increase the escalation of commitments.

\section{REFERENCES}

Abatecola, G., Caputo, A., \& Cristofaro, M. (2018). Reviewing cognitive distortions in managerial decision making: Toward an integrative co-evolutionary framework. Journal of Management Development, 37(5), 409-424.

Anthony, R. N., \& Govindarajan, V. (2012). Sistem Pengendalian Manajemen [Terjemahan] (edisi ke-11). Jakarta: Salemba Empat.

Badan Pusat Statistik. (2021). Jumlah kunjungan wisman ke Indonesia bulan Juni 2021 mencapai 140,85 ribu kunjungan. Didapatkan dari https://www.bps.go.id/pressrelease/2021/08/02/1802/jumlah-kunjungan-wisman-keindonesia-bulan-juni-2021-mencapai-140-85-ribu-kunjungan.html

Daft, R.L. (2014). Era Baru Manajemen [Terjemahan] (edisi ke-9). Jakarta: Salemba Empat.

David, F.R., \& David, F.R. (2016). Manajemen Strategik [Terjemahan] (edisi ke-15). Jakarta: Salemba Empat.

Guo, W., \& Cannella Jr, A. A. (2021). No Need to Know It All: Implications of COVID - 19 for Corporate Communication Research. Journal of Management Studies, 58(5), 1421.

Helmayunita, N. (2015). Pengaruh Adverse Selection, Kontrol Monitoring, Dan Penalaran Moral Individu Terhadap Perilaku Eskalasi Komitmen. Jurnal WRA, 3(1), 513-528.

Kalmanovich-Cohen, H., Pearsall, M.J., \& Christian, J.S. (2018). The effects of leadership change on team escalation of commitment. The Leadership Quarterly, 29(5), 597-608.

Kessler, E.H. (Ed.). (2013). Encyclopedia of management theory. California: Sage Publications Inc.

Moloi, T., \& Marwala, T. (2017). Advanced Information and Knowledge Processing (edisi ke1). Cham: Springer International Publishing.

Muna, B. N., \& Haris, L. (2018). Pengaruh pengendalian internal dan asimetri informasi terhadap kecenderungan kecurangan akuntansi. Jurnal Akuntansi, Ekonomi dan Manajemen Bisnis, 6(1), 35-44.

Nahartyo, E., \& I. Utami. 2015. Panduan praktis riset eksperimen. Jakarta: PT Indeks.

Panjaitan, M. (2018). Pemberian penghargaan (reward), hukuman (punishment) dan prestasi kerja karyawan: Suatu kajian teoritis. Jurnal Ilmiah METHONOMI, 4(1), 93-100.

Pramono, J. (2020). Pembangunan Wisata Tulungangung Terhambat Covid-19. Didapat dari https://jatimtimes.com/baca/213849/20200430/162500/pembangunan-wisatatulungagung-terhambat-covid-19, 15 Agustus 2021, pukul 20.17 WIB.

Pride, W.M., Hughes, R.J., \& Kapoor, J.R. (2017). Pengantar Bisnis [Terjemahan] (edisi ke11). Jakarta: Salemba Empat. 
The Determinants of Commitment Escalation (Experimental Study: Covid-19 Pandemic as A Contextual)

Patricia Felin Budianto and Dyna Rachmawati

Putri, C. M. (2018). Penerapan Skema Insentif, Tingkat Komitmen Organisasi dan Pengaruhnya Terhadap Escalation of Commitment. Ekspansi: Jurnal Ekonomi, Keuangan, Perbankan dan Akuntansi, 10(1), 59-70.

Radianto, W.ED. (2018). Akuntansi Kepenlakuan: Memahami lebih dalam eskalasi komitmen. Surabaya: PT Revka Petra Media

Ruggeri, K., Alí, S., Berge, M. L., Bertoldo, G., Bjørndal, L. D., Cortijos-Bernabeu, A., \& Folke, T. (2020). Replicating patterns of prospect theory for decision under risk. Nature human behaviour, 4(6), 622-633.

Sari, P., \& Wirakusuma, M. (2016). Pengaruh adverse selection dan negative framing pada kecenderungan eskalasi komitmen. E-Jurnal Ekonomi dan Bisnis Universitas Udayana Bali, 5(3), 573-600.

Schippers, M. C. (2021). Optimizing Decision-Making Processes in Times of COVID-19: Using Reflexivity to Counteract Information-Processing Failures. Frontiers in psychology, 12, 2261.

Scott, W.R. (2015). Financial Accounting Theory (edisi ke-7). Toronto: Pearson.

Selim, M. (2020). Escalation commitment in decision making and its possible effects in the long run. In 2020 International Conference on Decision Aid Sciences and Application, 686-691.

Soma, A. A., \& Restuti, M. M. D. (2017). Pengaruh informasi investasi, job rotation dan kondisi adverse selection terhadap eskalasi komitmen. Simposium Nasional Akuntansi XX Jember, 1-25.

Sulistiyo, H. (2019). Eskalasi komitmen terhadap proyek-proyek yang tidak menguntungkan: Pengaruh latar belakang pendidikan dan pengungkapan informasi sebagai pemodelan variabel. Eqien: Jurnal Ekonomi dan Bisnis, 6(2), 64-73.

Suwardjono. (2014). Teori Akuntansi Perekayasaan Pelaporan Keuangan (edisi ke-8). Yogyakarta: BPFE-Yogyakarta.

Yusra, M., \& Atika, S. (2017). Pengaruh Negative Framing dan Adverse Selection Terhadap Pengambilan Keputusan Eskalasi Komitmen. Jurnal Akuntansi dan Keuangan, 5(2), 9198.

Wong, K. F. E., \& Kwong, J. Y. Y. (2018). Resolving the Judgment and Decision-Making Paradox Between Adaptive Learning and Escalation of Commitment. Management Science, 64(4), 1911-1925. 